\title{
Mast/Stem Cell Growth Factor Receptor Kit
}

National Cancer Institute

\section{Source}

National Cancer Institute. Mast/Stem Cell Growth Factor Receptor Kit. NCI Thesaurus. Code C17328.

Mast/stem cell growth factor receptor Kit (976 aa, 110 kDa) is encoded by the human KIT gene. This protein is involved in cell survival, tyrosine phosphorylation and ligandmediated signaling. 